\title{
PENGARUH FREKUENSI PEMBERIAN PAKAN TERHADAP PERTUMBUHAN DAN KELANGSUNGAN HIDUP NENER BANDENG (Cbanos cbanos) DALAM BAK TERKONTROL
}

\author{
Daud S.Pongsapan"), Rachmansyah") dan Neltje N.Palinggi")
}

\begin{abstract}
ABSTRAK
Penelitian bertujuan untuk mengetahui pengaruh frekuensi pemberian pakan terhadap pertumbuhan dan kelangsungan hidup nener bandeng dalam bak terkontrol. Bak fiberglas ukuran $1,0 \times 0,5 \times 0,6 \mathrm{~m}$, diisi air sebanyak 200 liter dan ditebari nener bandeng dengan kepadatan 50 ekor/bak. Hewan uji diberi pakan komersial sebanyak $10 \%$ dari berat biomassa ikan uji. Sebagai perlakuan adalah frekuensi pemberian pakan yang disusun dalam rancangan acak lengkap, yaitu 1, 2, 3, dan 4 kali per hari, masing-masing terdiri dari tiga ulangan.
\end{abstract}

Hasil penelitian menunjukkan bahwa frekuensi pemberian pakan tiga dan empat kali sehari menghasilkan pertumbuhan berat mutlak terbaik. Laju pertumbuhan harian dan rasio konversi pakan berbeda tidak nyata $(\mathrm{P}>0,05)$ antara perlakuan. Tingkat kelangsungan hidup yang diperoleh berada pada kisaran 20-38,6\%. Tingkat kelangsungan hidup pada pemberian pakan 1, 2, dan 3 kali/hari serta pada pemberian pakan 2, 3 dan 4 kali per hari berbeda tidak nyata $(P>0,05)$.

Kisaran peubah kualitas air yang diamati selama penelitian masih berada pada rentang yang layak untuk mendukung kehidupan dan pertumbuhan ikan uji.

ABSTRACT: The Effect of Feeding Frequency on Growth and Survival Rate of Millfish (Cbanos cbanos) fry, by: Daud S.Pongsapan, Racbmansyab dan Neltje N.Palinggi

The aim of the experiment was to determine the effect of feeding frequency on the growth and survival rate of milkfish (Chanos chanos) fry. The fish was stocked at 50 ind. in a $1.0 \times 0.5 \times 0.6$ $\mathrm{m}$ in tank. Commercial pelet fed was given at a rate $10 \%$ of biomass/day. Four feeding frequencies, i.e. $1,2,3$, and 4 per day with three replicates each were set in a completely randomized design.

The best growth rate was achieved by 4 times feeding a day, followed by 3, 2, 1 time feeding a day. However, there were no significant difference $(P>0.05)$ among the treatment for daily growth rate and feed conversion ratio. The range of survival rate were $20-38.6 \%$ and they were no significant difference $(P>0.05)$ on survival rate among 1,2 , and 3 time feeding a day as well as among 2,3 , and 4 time feeding a day. fish.

Water quality monitored during the experiment were still within the tolerable limit for the

KEYWORDS: Feeding systems, milkfish

\section{PENDAHULUAN}

Penelitian mengenai aspek pengelolaan pakan masih sangat terbatas, sementara pakan merupakan satu di antara komponen biaya yang dapat menyerap sekitar 50-60\% biaya produksi. Anggawati et al. (1993) mengatakan bahwa pada budidaya ikan dalam keramba jaring apung biaya pakan dapat menyerap lebih dari $50 \%$ biaya produksi, sehingga perlu diupayakan penekanan 
biaya melalui penggunaan pakan secara efisien agar ikan dapat tumbuh optimal dan pakan yang terbuang seminimal mungkin.

Pada budidaya ikan beronang pemberian pakan berkali-kali dalam sehari memberikan respon pertumbuhan yang lebih baik jika dibandingkan dengan pemberian pakan sekali sehari dengan jumlah pakan yang sama (Martosewojo et al., 1983; Pongsapan et al., 1994). Hal seperti ini diduga akan terjadi pada jenis ikan herbifor lainnya seperti ikan bandeng.

Bertitik tolak dari hal tersebut maka telah dilakukan penelitian untuk mengetahui pengaruh frekuensi pemberian pakan terhadap pertumbuhan dan kelangsungan hidup nener bandeng dalam bak terkontrol. Hasil penelitian ini diharapkan dapat memberikan informasi tentang cara pengelolaan pakan secara ekonomis.

\section{BAHAN DAN METODA}

Penelitian dilakukan di Instalasi penelitian Balitkanta di Teluk Labuange Kabupaten Barru Propinsi Sulawesi Selatan, selama 5 minggu (AgustusSeptember 1994). Wadah berupa tangki fibreglass ukuran $1,0 \times 0,5 \times 0,6 \mathrm{~m}$, diisi air laut yang telah disaring dengan filter bag masing-masing sebanyak 200 liter, dilengkapi dengan aerasi dan ditempatkan dalam sebuah ruangan secara acak. Pergantian air dilakukan setiap hari sebanyak $30 \%$ dari volume tangki dengan menggunakan pipa plastik ukuran $1 / 4$ inci, setelah selesai penyiponan sisa-sisa pakan dan kotoran ikan.

Nener bandeng sebagai hewan uji berukuran rata-rata $0,80 \mathrm{~g} /$ ind. dan diperoleh dari pedagang pengumpul nener di Kalibone Pangkep. Adaptasi benih terhadap pakan dan air laut dilakukan selama satu minggu. Pakan komersial berkadar protein $40 \%$ diberikan dengan dosis $10 \%$ dari berat biomas/ hari (Lim et al., 1979). Padat penebaran yang diaplikasikan dalam penelitian ini adalah 50 ind./tangki. Perlakuan adalah frekuensi pemberian pakan masingmasing satu kali, dua kali, tiga kali, dan empat kali per hari. Masing-masing perlakuan terdiri dari tiga ulangan dan dirancang dalam rancangan acak lengkap (RAL). Perubahan jumlah pakan dilakukan setiap minggu setelah selesai penimbangan, disesuaikan dengan perubahan bobot tubuh ikan uji.

Penimbangan ikan uji dilakukan setiap minggu terhadap seluruh ikan uji dengan menggunakan timbangan elektrik merek AND ketelitian 0,1 g. Sedang pertumbuhan mutlak dan kelangsungan hidup dihitung pada akhir percobaan. Laju pertumbuhan harian dihitung berdasarkan rumus NRC (1977), kelangsungan hidup dan rasio konversi pakan dihitung berdasarkan rumus Sedgwik (1979). Dalam perhitungan rasio konversi pakan diasumsikan bahwa semua pakan yang diberikan dapat dimanfaatkan oleh ikan uji. Hal ini disebabkan karena sisa pakan yang tidak termakan sangat sulit dipisahkan dari partikel lainnya seperti hancuran feses serta bahan-bahan organik pada saat penyiponan. 
Untuk mengetahui kelayakan media bagi kelangsungan hidup ikan uji maka dilakukan pemantauan terhadap beberapa peubah kualitas air seperti salinitas, suhu, $\mathrm{pH}$, oksigen terlarut, bahan organik, fosfat dan nitrat yang dilakukan setiap minggu.

Untuk mengetahui pengaruh perlakuan terhadap pertumbuhan, kelangsungan hidup dan rasio konversi pakan maka dilakukan analisis sidik ragam dengan bantuan paket program statistik. Jika diperoleh pengaruh yang nyata dari perlakuan yang dicobakan, maka dilakukan uji lanjut Tukey untuk mengetahui pengaruh perbedaan antar perlakuan. Sedangkan kelayakan habitat dianalisa secara deskriptif.

\section{HASIL DAN PEMBAHASAN}

Hasil pengamatan pertumbuhan berat ikan uji selama 5 minggu membuktikan bahwa pemberian pakan 4 kali per hari lebih baik dari pemberian pakan 3, 2, dan 1 kali per hari. Pertumbuhan berat individu pada pemberian pakan 4 kali per hari mencapai $0,90 \mathrm{~g}$ disusul perlakuan 3, 2, 1 kali per hari masing-masing 0,$85 ; 0,83$ dan $0,68 \mathrm{~g}$ (Gambar 1).

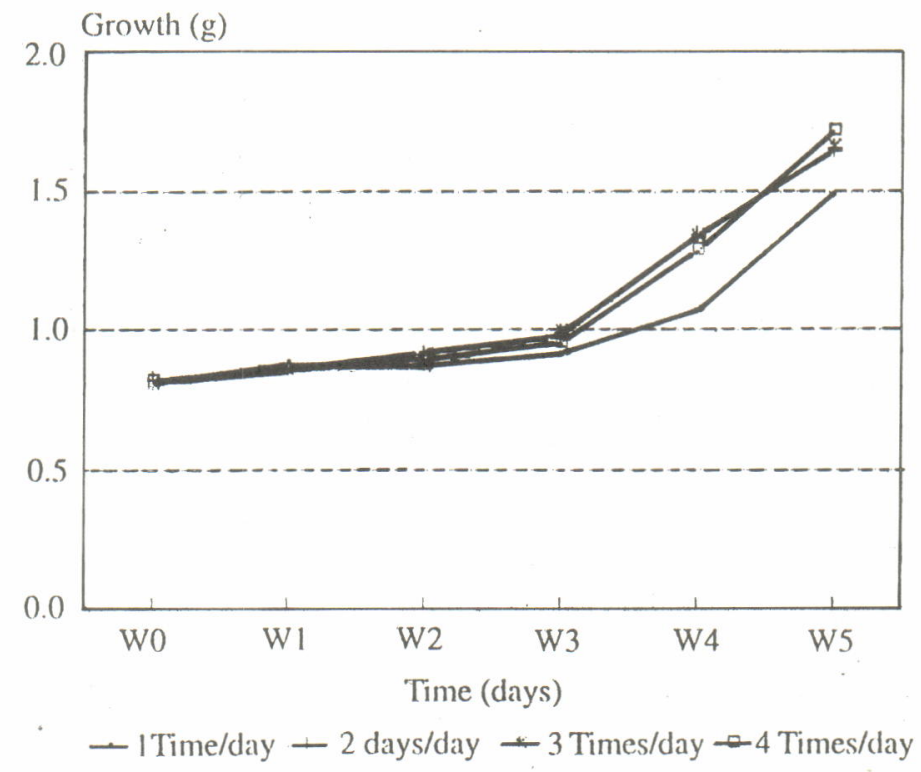

Gambar 1. Pertumbuhan berat mutlak nener bandeng selama 35 hari Figure 1. Absolute growth of milkfish (Chanos chanos) fry at different feeding frequency for 35 days 
Laju pertumbuhan yang diperoleh pada percobaan ini berada pada kisaran $1,67-2,04 \%$. Laju pertumbuhan tertinggi diperoleh pada pemberian pakan $4 \mathrm{kali}$ per hari yaitu 2,04 kemudian diikuti pada perlakuan 3, 2, dan 1 kali per hari masing-masing berturut-turut 1,$98 ; 1,90$ dan $1,67 \%$. Hasil analisis ragam menunjukkan bahwa perlakuan yang dicobakan tidak memperlihatkan perbedaan yang nyata (Tabel 1), namun pada pemberian pakan dengan frekuensi pemberian yang lebih banyak cenderung memperlihatkan respon pertumbuhan yang lebih baik. Hal serupa juga dijumpai oleh Teshima et al. (1984) pada pemeliharaan nener bandeng berukuran awal $82-86 \mathrm{mg}$ pada bak terkontrol, dengan pemberian pakan berkadar protein $50 \%$ diperoleh pertambahan berat mutlak terbaik yaitu $170,3 \pm 30,9 \%$ dari berat awal pada perlakuan pemberian pakan 2 kali sehari dibandingkan dengan 1 kali sehari selama 20 hari pemeliharaan. Selanjutnya Sineriches dan Chiu (1988) pada penelitian perbedaan protein dengan sumber protein yang berbeda, mendapatkan pertumbuhan terbaik pada pada larva bandeng yang diberi pakan dengan kadar protein $39,2 \%$. Selanjutnya Susanto et al. (1992) pada penelitian dengan kadar protein yang berbeda $(20,30$, dan $40 \%)$ pada larva bandeng berat awal $0,009 \mathrm{~g}$ selama 60 hari dalam bak terkontrol, mendapatkan pertumbuhan berat mutlak dan kelangsungan hidup terbaik pada perlakuan $40 \%$ protein yaitu masing- masing $3,32 \mathrm{~g}$ dan $99,5 \%$.

Tabel 1. Laju pertumbuhan harian, kelangsungan hidup dan rasio konversi pakan nener bandeng selama 35 hari

Table 1. Daily growth rate, survival rate and food conversion ratio of milkfish fry at different feeding frequency for 35 days

\begin{tabular}{|c|c|c|c|c|}
\hline \multirow[t]{2}{*}{ Variabel } & \multicolumn{4}{|c|}{$\begin{array}{l}\text { Frekuensi pemberikan pakin (kalifhari) } \\
\text { Feeding frequency (time/day) }\end{array}$} \\
\hline & 1 & 2 & 3 & 4 \\
\hline Berat awal (g/ind.) & 0,81 & 0,82 & 0,80 & 0,81 \\
\hline Berat akhir (g/ind.) & 1,49 & 1,64 & 1,65 & 1,71 \\
\hline Kenaikan berat total ( $g /$ tangki) & 39,44 & 34,44 & 39,10 & 27,00 \\
\hline Kelangsungan hidup (\%) * & $38,60 \mathrm{~b}$ & $28,00 \mathrm{ab}$ & $30,60 \mathrm{ab}$ & $20,00 \mathrm{a}$ \\
\hline Tingkat pertumbuhan harian $(\% /$ hari $)$ * & 1,67 a & $1,90 \mathrm{a}$ & $1,98 \mathrm{a}$ & $2,04 \mathrm{a}$ \\
\hline Total pemberian pakan (g/tangki) & 108,60 & 107,20 & 104,40 & 92,20 \\
\hline Rasio konversi pakan (FCR) * & 2,75 a & 3,11 a & 2,67 a & 3,40 a \\
\hline
\end{tabular}

Angka pada baris yang sama diikuti buruf serupa adalab tidak berbeda nyata (The values in the same row followed by similar letters are not dignificantly different) $(P>0.05)$

\section{Kelangsungan Hidup}

Persentase tingkat kelangsungan hidup yang diperoleh pada percobaan ini berkisar $20-38,6 \%$ (Tabel 1). Kelangsungan hidup tertinggi diperoleh pada 
pemberian pakan 1 kali sehari, kemudian disusul perlakuan pemberian pakan 3 kali, 2 kali, dan 1 kali per hari masing-masing 30,6; 28 dan 20\%. Kisaran nilai tersebut masih lebih baik dibandingkan dengan hasil penelitian sebelumnya oleh Lim et al. (1979) pada larva ikan bandeng dengan berat awal 0,04 $\mathrm{g}$ yang diberi pakan dengan kadar protein $20-60 \%$ yaitu $7,5-30 \%$, namun lebih kecil dibandingkan dengan hasil penelitian Sineriches dan Chiu (1988) pada nener bandeng dengan berat awal rata-rata $0,008 \mathrm{~g}$ dan diberi pakan dengan kadar protein $39,2 \%$ yaitu $63 \%$.

Hasil analisis ragam menunjukkan bahwa antara perlakuan pemberian pakan 1, 2, dan 3 kali per hari tidak memperlihatkan perbedaan yang nyata $(P>0,05)$, juga antara pemberian pakan 2, 3, dan 4 kali per hari. Namun pemberian pakan 1 kali per hari memperlihatkan perbedaan yang nyata $(P<0,05)$ dengan pemberian pakan 4 kali per hari (Tabel 1). Kematian ikan mulai terjadi pada minggu ke dua sampai dengan minggu ke tiga. Hasil pengamatan di Laboratorium menunjukkan bahwa kematian ikan diduga disebabkan oleh pakan yang terkontaminasi bakteri sebagai akibat penyimpanan yang terlalu lama. Hasil perhitungan jumlah bakteri pada media TCBS yang merupakan kontaminasi pada pakan khususnya pada minggu ke 2 dan 3 adalah $48 \times 10^{3}-7,5 \times 10^{4} \mathrm{sel} / \mathrm{ml}$. Jumlah tersebut sudah dapat mematikan ikan. Di samping itu kematian ikan juga diakibatkan oleh penanganan penimbangan yang belum sempurna.

\section{Rasio Konversi Pakan}

Rasio konversi pakan berada pada kisaran 2,6-3,4. Rasio konversi pakan yang diperoleh pada percobaan ini lebih tinggi jika dibandingkan dengan hasil penelitian sebelumnya oleh Lim et al. (1979) pada nener bandeng yang diberi pakan dengan kadar protein $20,30,40,50$ dan $60 \%$ dengan dosis $10 \%$ dari berat biomas ikan uji dengan konversi pakan masing-masing 2,46; 2,2; 1,96; 1,99 dan 2,02. Selanjutnya Sineriches dan Chiu (1988) mendapatkan rasio konversi pakan pada nener bandeng yang diberi pakan dengan kadar protein 35,$3 ; 38,4 ; 39,2 ; 39,8$ dan 40,6 masing-masing 4,$9 ; 1,8 ; 1,5 ; 7,1$ dan 7,1.

Penyebab tingginya rasio konversi pakan pada percobaan ini diduga ada kaitannya dengan jumlah pakan yang diberikan dan volume tangki. Hal seperti ini dijumpai pada perlakuan pemberian pakan 3, 4, kali per hari dimana jumlah pakan yang diberikan per satu kali pemberian berkisar antara 1-1,5 g untuk volume 200 liter, sehingga peluang ikan untuk mendapatkan pakan sangat kecil, sementara perhitungan rasio konversi pakan diasumsikan bahwa semua pakan yang diberikan dapat dikonsumsi oleh ikan uji. Selanjutnya Schmittou (1991) mengatakan bahwa tinggi rendahnya rasio konversi suatu pakan dipengaruhi oleh beberapa faktor terutama kualitas dan kuantitas pakan, jenis dan ukuran ikan serta kualitas air. 
Secara keseluruhan, perlakuan pemberian pakan tiga kali per hari cenderung memberi respon yang lebih baik terhadap laju pertumbuhan harian, rasio konversi pakan serta kelangsungan hidup.

\section{Kualitas Air}

Kualitas air mempunyai peranan penting sebagai pendukung kehidupan dan pertumbuhan ikan uji. Hasil pemantauan terhadap beberapa variabel kualitas air yang meliputi salinitas, $\mathrm{pH}$, oksigen terlarut, suhu, nitrat dan fosfat disajikan pada Tabel 2.

Tabel 2. Kisaran dan rata-rata nilai peubah kualitas air yang dimonitor selama percobaan

Table 2. Range and average of water quality variables monitored during the experiment

\begin{tabular}{|c|c|c|c|}
\hline $\begin{array}{l}\text { Variabel } \\
\text { Variables }\end{array}$ & & $\begin{array}{l}\text { Kisaran } \\
\text { Range }\end{array}$ & $\begin{array}{l}\text { Rata-rata } \\
\text { Average }\end{array}$ \\
\hline Salinitas (salinity) & ppt & $32,0-35,0$ & $32,0 \pm 1,09$ \\
\hline Suhu (temperature) & ${ }^{\circ} \mathrm{C}$ & $24,9-28,0$ & $26,1 \pm 0,98$ \\
\hline Oksigen terlarut $(D O)$ & ppm & $5,0-7,3$ & $6,40 \pm 0,98$ \\
\hline $\mathrm{pH}$ & & $7,5-8,5$ & $7,90 \pm 0,30$ \\
\hline PO4-P & ppm & $0,00260-0,03147$ & $0,0159 \pm 0,0093$ \\
\hline NO3-N & ppm & $0,0041-0,0049$ & $0,0043 \pm 0,0020$ \\
\hline
\end{tabular}

Berpedoman pada Anggoro (1984) serta Ahmad et al. (1991) dapat disimpulkan bahwa kondisi kualitas air yang dimonitor selama berlangsungnya percobaan masih berada pada rentang yang layak untuk mendukung kehidupan dan pertumbuhan ikan uji.

\section{KESIMPULAN}

Disimak dari laju pertumbuhan, rasio konversi pakan serta tingkat kelangsungan hidup, maka pemberian pakan tiga kali per hari terbaik bagi nener.

\section{UCAPAN TERIMA KASIH}

Ucapan terima kasih disampaikan kepada teknisi litkayasa Sdr. Rosiana Sabang, Reni Yulianingsih, Sutrisyani dan Johannes Teken yang telah banyak membantu dalam penelitian ini baik di Laboratorium maupun di lapangan. 


\section{DAFTAR PUSTAKA}

Ahmad.T., P.T.Imanto, Muchari, A.Basyarie, P.Sunyoto,B.Slamet, Mayunar, R.Purba, S.Diani, S.Redjeki, S.A.Pranowo dan S.Murtiningsih, 1991. Operasional Pembesaran ikan kerapu dalam keramba jaring apung. Badan Litbang Pertanian, Balai Penelitian Perikanan Budidaya Pantai, Maros 59 hal.

Anggawati A.M., Krismono I.P., S. Ilyas, dan S.Putro, 1993. Inventarisasi jenis pakan dan strategi pemberian pakan untuk berbagai jenis ikan budidaya pada type dan lingkungan budidaya di Jawa Barat dan Jawa Tengah. Bull. Penel.Perikanan (5): 95-116.

Anggoro S., 1984. Pengaruh salinitas terhadap kuantitas dan kualitas makanan alami serta produksi biomass nener bandeng. Thesis Fakultas Pasca Sarjana Institut Pertanian Bogor. 109 hal.

Lim C., S.Sukwahongs, and F.P.Pascual, 1979. A. Preliminary study on the protein requirement of Chanos chanos Forskal fry in a controlled environment. Aquaculture (17): 195-201.

Martosewojo S., Burhanuddin, A.Jamali, dan P.Sianipar, 1983. Ikan beronang: Biologi, potensi dan pengelolaan. Proyek Studi Potensi Sumberdaya Ekonomi. Lembaga Oceanologi Nasional, LIPI Jakarta, 43 hal.

National Research Council (NRC), 1977. Requirement of Warmwater fishes. National Academic Sciences. Washington D.C. 78p.

Pongsapan D.S., S.Tonnek, N.Kabangnga, dan Usman, 1984. Pengaruh Pakan tenggelam dan terapung terhadap produksi nila merah Oreocbromis niloticus dalam keramba jaring apung di laut. J.Penel. Budidaya Pantai 9(4): 75-84.

Sedgwick R.W., 1979. Influence of dietary protein and energy on growth, food consumption, and food convertion efficeincy in Penaeus monodon de Man. Aquaculture (16): 7-30.

Sineriches M.L.M., and Y.N.Chiu, 1988. Effect of fishmeal on the growth, survival and feed efficiency on milkfish (Chanos chanos) fry. Aquaculture 71(1/2): $61-79$.

Schmittou H.R., 1991. Cage culture: A method of fish production in Indonesia. FRDP Central Research Institute for Fisheries. Jakarta Indonesia. 115 p.

Susanto B., T.Ahmad, dan K.Wahyudi, 1992. Pemberian pakan dengan beda kandungan protein terhadap pertumbuhan benih bandeng (Chanos chanos). Warta Balitdita 4(2): 1-5.

Teshima S.I., A.Kanazawa, and G.Kawamura, 1984. Effect of several factor on growth of milkfish (Chanos chanos Forskal) fingerlings reared with artificial diets in aquaria. Aquaculture 37(1): 39-50. 